\title{
Peindre l'espace littéraire aux couleurs du temps. Introduction
}

\author{
Painting the Literary Space with the Colors of Time. Introduction
}

L'espace est le point nodal sur lequel repose toute étude en géocritique. Il peut prendre des formes multiples, il se dilate ou se contracte et s'enlace au temps pour former un concept hybride au diapason avec la science moderne. Bertrand Westphal, chef de file de la géocritique, met en exergue la dynamique du métissage de l'espace-temps selon la métaphore du « temps fleuve » (Westphal, 2007, p. 19) qui renvoie à la suprématie de l'espace vu que le temps ne se mesure plus que par les effets de l'écoulement spatial. Westphal insiste également sur l'importance du relativisme einsteinien dans l'épanouissement du nouvel espace littéraire contemporain. En ce sens, il recrée la manière de le percevoir non plus comme une entité constante et immuable, mais plutôt comme une étendue changeante et en mouvement continu. À l'ère postmoderne, le texte littéraire joue sur la multiformité de l'espace et devient pluriel, maniable, changeant et hétérogène. Il dépasse la simple représentation de lieux naturels ou urbains qui éclosent au sein de la fiction pour véhiculer, par leur intermédiaire, l'idéologie de l'auteur.

À l'inverse des autres approches qui se livrent principalement à l'analyse des représentations textuelles des lieux, la théorie géocritique de Westphal (2007) s'intéresse à l'espace dans le texte littéraire à travers les interactions entre les différentes aires et la manière dont elles reflètent le rapport de l'homme avec son environnement. Westphal se repose sur trois axes pour mettre en lumière sa réflexion sur la géocritique. Le premier est « une réflexion sur la spatiotemporalité... » (p. 17) censée montrer une nette revalorisation de l'espace au cours du dernier siècle ainsi que l'évolution de la perception du temps qui tend à se spatialiser progressivement. Le deuxième tourne autour de « la mobilité »

Loubna Achheb, Department of French Language and Literature, Mohamed Lamine Debaghine-Sétif 2 University, 19000 Setif, lou.achheb@yahoo.fr, http://orcid.org/0000-0002-5707-1489

Anna Maziarczyk, Katedra Romanistyki, Instytut Neofilologii, PI. Marii Curie-Skłodowskiej 4a, 20-031 Lublin, Phone: 0048815372664, anna.maziarczyk@poczta.umcs.lublin.pl,

https://orcid.org/0000-0001-8485-0915 
(p. 17) de l'espace contemporain et tente de saisir son instabilité foncière. Enfin, le troisième axe est centré sur « la référentialité, la nature du lien entre le réel et la fiction, entre les espaces du monde et les espaces du texte » (p. 17). Il s'agit d'interroger les relations entre les espaces réels et leurs diverses représentations, littéraires ou autres, afin de voir comment elles contribuent à (re)créer le monde.

Le présent volume thématique de la revue Lublin Studies in Modern Languages and Literature se propose d'exploiter les fondements de la théorie géocritique comme outil d'analyse des espaces fictionnels. Il renferme plusieurs articles sur l'espace-temps, les espaces réels et imaginaires ainsi que la mobilité de ces aires. En étudiant les œuvres littéraires de diverses époques, aussi bien françaises que francophones, les auteurs scrutent les manières dont les lieux se trouvent inscrits dans les textes, reflétés, (re)construits ou engendrés à travers les mots et réfléchissent sur les enjeux de cette reprise du réel dans le littéraire.

$* * *$

Space proves pivotal to every geocritical study. It takes many forms, expands or contracts, entwines with time to create a hybrid concept in line with modern science. Bertrand Westphal, the leader of geocriticism, draws on the "rivertime" metaphor to highlight the interweaving of space and time (2007, p. 19). The notion points to the superiority of space since time can only be measured by spatial flow. Westphal also argues for the role of Einsteinian relativism in developing the new contemporary literary space. In that same vein, he reinvents the way space is seen - no longer as a constant and unchanging entity but rather as a flexible and ever fluctuating expanse. In the postmodern era, the literary text exploits the multiformity of space and thus becomes plural, manageable, changeable and heterogeneous. It goes far beyond a simple representation of natural and urban areas that emerge within the fictional world to convey the author's ideology.

Unlike other approaches centred on textual representations of places, Bertrand Westphal's geocritical theory explores space in the literary text through interactions between different areas and the way they reflect humans' relationship with their surroundings. To bring to life his understanding of geocriticism, Westphal relies on three concepts. The first one incorporates "thoughts on spatiotemporality..." (2007, p. 17), proving that over the last century the idea of space has been reevaluated while the time has gradually become viewed as spatial. The second one revolves around the idea of "mobility" (2007, p. 17) of contemporary space to capture its fundamental instability. Finally, the third concept focuses on "referentiality, the nature of the link between reality and fiction, between spaces of the world and spaces of the text" (2007, p. 17). It involves the study of relations between real spaces and their different literary and non-literary representations to see how they contribute to the (re)creation of the world. 
The present volume of Lublin Studies in Modern Languages and Literature explores the central premises of the geocritical theory as a tool for analysis of fictional spaces. It includes a number of papers on space-time, real and imaginary spaces and their mobility. By studying French and Francophone literature from different periods, the authors examine how words used in literary words give rise to, -reflect, (re)create, and produce spaces, and they ponder on the importance of this reinterpretation of reality in literature.

\section{References}

Westphal, B. (2007). La Géocritique. Réel, fiction, espace. Paris: Minuit. 